\title{
Editorial: Traditional bibliographic instruction and today's information users
}

\begin{tabular}{|c|c|}
\hline Purpose of this paper & $\begin{array}{l}\text { This paper takes forward strands from } \\
\text { 'Evaluating the quality of library portals' } \\
\text { (Joint, 2005) and places them in the } \\
\text { context of different approaches to teaching } \\
\text { students about information use. }\end{array}$ \\
\hline Design/methodology/approach & $\begin{array}{l}\text { An opinion piece which examines the impact } \\
\text { on user behaviour of traditional mechanical } \\
\text { library skills training (such as 'library } \\
\text { orientation', 'bibliographic instruction', or } \\
\text { 'information skills training' rather than true } \\
\text { information literacy-based teaching). The } \\
\text { paper points out the similarity in the effects } \\
\text { of such teaching to the effects of offering } \\
\text { users a more powerful mechanical } \\
\text { information retrieval tool (such as a library } \\
\text { portal or internet search engine) without } \\
\text { effective support on how the information } \\
\text { retrieved should be used for significant } \\
\text { educational outcomes. }\end{array}$ \\
\hline Findings & $\begin{array}{l}\text { For librarians to be custodians of the } \\
\text { highest standards of intelligent information } \\
\text { use, they must demonstrate a meaningful, } \\
\text { rather than a mechanical understanding and } \\
\text { application of information literacy in their } \\
\text { everyday practice. Without this, information } \\
\text { users will rightly turn to new, non-mediated } \\
\text { forms of information use such as Internet } \\
\text { search engines, which can deal with purely } \\
\text { technical challenges of information retrieval } \\
\text { superficially well. Both the users and the } \\
\text { profession itself will be the poorer as a } \\
\text { result. }\end{array}$ \\
\hline $\begin{array}{l}\text { Research } \\
\text { limitations/implications }\end{array}$ & $\begin{array}{l}\text { An expression of opinion about the dangers of } \\
\text { pedagogically underdeveloped user education on } \\
\text { user behaviour. }\end{array}$ \\
\hline Practical implications & $\begin{array}{l}\text { This opinion piece gives some clear and practical } \\
\text { insights for the application of information } \\
\text { literacy principles to library practice. }\end{array}$ \\
\hline $\begin{array}{l}\text { What is original/value of the } \\
\text { paper? }\end{array}$ & $\begin{array}{l}\text { This piece points out the ironic similarities in the } \\
\text { effect of a mechanistic or tool-based approach } \\
\text { to user education and unmediated user access } \\
\text { to internet search engines or Library portals: } \\
\text { above all, a 'more is better' approach in the } \\
\text { information user, marked by citing too } \\
\text { much poorly digested, poorly evaluated } \\
\text { data. }\end{array}$ \\
\hline
\end{tabular}

This is a peer-reviewed author accepted manuscript of the following research article: Joint, N. (2005), "Traditional bibliographic instruction and today's information users", Library Review, Vol. 54 No. 7, pp. 397-402. https://doi.org/10.1108/00242530510611884 
Keywords: Libraries; Information Services; Literacy.

\section{Introduction}

Previously in LR 546 we reflected on the irony that portals, as the library's response to the popularity of non-library internet search engines, might encourage and reproduce some of the problematic patterns of user information behaviour we associate with those very same internet search engines (Joint, 2005). These patterns have been summed up in the phrase the 'satisfied and inept' user (Plutchak, 1989). This phrase can be applied to the user of internet search engines who is pleased at the ease of the retrieval facilitated by these tools but who remains content with the most easily retrieved data rather than the best possible information. The processes whereby we distinguish between 'the easiest' and 'the best' are acts of intellectual effort and purposefully engaged mental discrimination from which no mediating computer system, however sophisticated, can offer absolution. Or, to put it another way, the trouble with education is, you have to think long and hard or it just doesn't happen.

Unintelligent patterns of information retrieval and use can be seen as the result of offering users powerful search tools without appropriate guidance on the information literate use of such tools. The library portal is one of these powerful search tools, just as much as Google. Paradoxically, things might appear to have been better in the days when information retrieval without IT was harder. 'Harder' was 'better', because the recognition of difficulty as intrinsic to information-based learning meant that, in some mysterious and slightly masochistic way, challenging learning tasks were core to library use.

This nostalgia is more than a little illusory. Information retrieval before the advent of pervasive Library IT did indeed recognise the intrinsic nature of 'difficulty'. However, much of this difficulty was a mechanical difficulty rather than the labour pains of hard thought provoked by the discovery of original information. Indeed the laboriousness of traditional library information retrieval could even distract librarian educators from the intelligent use of library tools in favour of a preoccupation with technicalities and mechanical skills. It is worth recalling that the term 'information literacy' came to prominence in the 1970s when the massive impact of online information retrieval via mainframe computers was being felt for the first time (Zurkowski, 1974) - this implies that advances in Library IT enhanced our thinking about how to use information intelligently, not the opposite, and did so by removing some of the mechanical difficulties of information retrieval.

I would like to argue that it is in fact possible to create poor patterns of information use by providing a traditional form of purely mechanistic information skills training, even though the skills imparted may be quite technically complex ones and quite interesting for the naïve user to master. But, in order to be redeemed from a state of 'satisfied ineptitude', library users must be offered support in genuinely educational library use, not purely skills-based information use. Whether the tools are traditional

This is a peer-reviewed author accepted manuscript of the following research article: Joint, N. (2005), "Traditional bibliographic instruction and today's information users", Library Review, Vol. 54 No. 7, pp. 397-402. https://doi.org/10.1108/00242530510611884 
or digital is irrelevant. This support - which has only adequately been defined by the information literacy movement - must aim at eliciting the higher level learning outcomes for which improved information retrieval skills are merely a platform, not an end in themselves.

\section{Practical experience}

In partial proof of this, let me describe in very general terms some personal early experiences of user education in the 1990s when I was not long out of the venerable institution then known as 'library school' (now known as an information science department) and was working on improving library use among trainee technology teachers in Scottish Higher Education. At that time, in the mid-1980s and early 1990s, many, if not most library school graduates in the UK would not have received user education training as a core part of postgraduate LIS education. In consequence, the type of user education we offered in our early professional practice was rarely supported by well-developed pedagogic theory or principle.

This was in spite of the fact that, as pointed out above, Paul Zurkowski (op cit.), President of the Information Industry Association, had been the first to use the term information literacy a decade or so earlier. The ALA's seminal work on information literacy then followed in 1989, and Eisenberg and Berkowitz's big six skills were developed in rapid succession (1990). UK user education practice in the mid-1980s and early 1990 s was seemingly insulated from these developments. Logically therefore, much 'user education' work undertaken then without the pedagogy of 'information literacy' was likely to be defective.

Frankly, library user orientation in the UK at that time could be pragmatic and pedestrian, with an emphasis on imparting concrete, reliable formulae for using the immediately available library services at hand. An emphasis on the specifics of particular tools was not uncommon: 'This is how the catalogue/Index Medicus/your essential periodical index works memorise and use'. No real emphasis here on transferable skills, just nononsense training for a given collection, (or later) for the early text-based database interfaces that were starting to appear over campus networks, and which have been described elsewhere (Duff, 2003).

To be fair, given the unfamiliarity of many of these new database services, and the clunky feel of their text-based, 'chui' interfaces (character-based user interfaces), adopting a line by line teaching approach based on a mechanical explanation of their front-ends was not without value. But this was not user education based on the principles of 'information literacy'.

\section{New educational thinking}

However, many progressive educationalists in Secondary and Higher Education were at that very same time moving away from the equivalent, mechanistic forms of teaching in their own mainstream subjects. In Scotland for example, where my professional experience was gained,

This is a peer-reviewed author accepted manuscript of the following research article: Joint, N. (2005), "Traditional bibliographic instruction and today's information users", Library Review, Vol. 54 No. 7, pp. 397-402. https://doi.org/10.1108/00242530510611884 
attention was turning to new ways of teaching trainee technology teachers, with a particular emphasis on learning technology as a transformational medium (for example, The TLTSN initiative, 1995-1998). The emphasis was on independent learning (rather than covering a complete body of received learning) and great value was placed on the use of personally gathered information to create new solutions for engineering problems. The ability to be a fully self-empowered, skilful information seeker was core to this pedagogic vision of the engineer as an independent learner rather than a mere regurgitator of a syllabus of transmitted technical facts and formulae.

\section{The Library's role}

And as part of this process of reinventing the engineering teaching curriculum in $\mathrm{HE}$, the University Library would be asked to supply the information skills teaching that could support independent learning in original project assignments. At this time I was one of a team of librarians called upon to develop a compulsory, assessed information skills component to be added to a tertiary level technology teacher training course, and which, for several years thereafter, contributed a number of marks to the final year-end scores of the students in question.

For the students, the informing pedagogy of our information skills contribution came from the wider educational goals of their course itself. This made up for the fact that what the Library was offering was typical of the day - mechanical tool-based, 'transmission'-style library teaching. Many of the stronger students managed to contextualise this mechanistic approach by reference to the aims of their overall degree. They produced good project reports - that is, the valuable, original data they found via literature searching they then applied selectively and intelligently to their project topic. The weaker students floundered, although they did get quite good at mechanistic information retrieval. This led to a number of weak project reports which were characterised by unnecessarily long bibliographies of dubious relevance to the projects in question. The impression had been given by our interventions that 'more references were better' and gained more marks - information retrieval seemed to be a mechanical skill than could be measured in quantity rather than by the quality of the students' application of the information to the educational task in question.

\section{Changing the pedagogy of user education}

After two years of this trend, the Library decided to raise its game. As such, this was an interesting example of librarians taking responsibility for the way the information which they supplied was used - we couldn't just provide the resources, explain the mechanics of using them and then ask the students to get on with it. We wanted to be viewed as responsible for the educational application of this information as well.

The problem was not that the weaker students were bad at getting hold at information - rather the opposite, they were enthusiastic and became quite skilled at finding and compiling extensive lists of references from

This is a peer-reviewed author accepted manuscript of the following research article: Joint, N. (2005), "Traditional bibliographic instruction and today's information users", Library Review, Vol. 54 No. 7, pp. 397-402. https://doi.org/10.1108/00242530510611884 
catalogues, indexes and databases. They just couldn't evaluate, sift and then apply the most relevant references to the specific project topic they had chosen. There was a lack of information literacy both in their information skills teaching and in their resultant academic activity.

The challenge here was to find a way of encouraging the weaker students to stand back and ask questions about the quality of their information use. It was clear that the low performers could not see the faults in their work, and in fact our well-intentioned librarians' interventions seemed to have blurred their perceptions of what was good and what was poor information use. It would have been unkind to say that the weakest students were 'satisfied' with their 'ineptitude', but in retrospect, they were showing many of the symptoms now attributed to indiscriminate, unsupported use of internet search engines (and user education is supposed to be the answer to this!).

\section{Changing the techniques of user education}

Fortunately, a hint of a way forward was provided when one student (who himself had produced a weak report) happened to read and comment on the faults of a similarly weak report from the previous year. He noted to us in passing the excessive length of the bibliography and the lack of its direct relevance to the topic in question. This was something of a 'Eureka' moment. It is a cliché that we see others' faults while blind to the same in ourselves, but that was what seemed to be happening with this student. If we as Librarian-teachers were struggling to show students how to use information literately, perhaps the answer was to provide concrete examples of how to apply these skills and how not to. Good and bad project reports from previous years could be distributed to demonstrate the difference between varying degrees of information literacy and information illiteracy.

Of course, the difficulty with this strategy is that it would have been nice for the strong student to be applauded, but hardly fair for the weaker student to be cited for years afterwards as the epitome of bad project writing. So, in the end, we turned to a literary genre for help - we wrote a concise parody of a bad project report, including in it all the faults we wished the students to avoid while preserving a certain quality of content. This meant that no individual's work was stigmatised as weak and also gave us control of the qualities and faults we wished the example to demonstrate. It was particularly useful for the parody to be in many ways well written and fairly effective in content - the specific fault we wished to highlight was how the information content was tacked on to the real thinking of the project. The 'real thinking' seemed to inhabit a different realm from the sections generated by the literature searching.

\section{Positive results}

The result of this strategy was a marked improvement in the overall quality of all projects in the subsequent third year. Above all, bibliographies were more concise, and what was cited tended to be used intelligently in the text of the project. Whereas before we had generated a

This is a peer-reviewed author accepted manuscript of the following research article: Joint, N. (2005), "Traditional bibliographic instruction and today's information users", Library Review, Vol. 54 No. 7, pp. 397-402. https://doi.org/10.1108/00242530510611884 
sense of panic in the students about not having long lists of references, we had now generated an awareness of the danger of producing long lists of irrelevant material that were not integrated into the core writing of the project. A negative incentive perhaps, but one that had positive results. The students had gained educationally and we as librarians had spent three years discovering what information literacy really meant (LIS educators please note!). Although this experience could be viewed as a form of continuing professional development, it probably would have been better to have introduced these concepts at Library school. Fortunately, things are better now in terms of the LIS curriculum in our informatics and information science departments.

\section{Conclusion}

Much present day commentary on internet search engines tends, for good reason, to talk about the downside of easy information retrieval.

Scepticism about equivalent dangers in Library portal usage is similar in tone and nature (Joint, op. cit.). This line of commentary is well founded.

However, this school of thought may appear characterised by some facile assumptions. It tends to imply that librarian support for information use is always necessary and good, and that 'difficulty' in information retrieval (associated with traditional patterns of library use) has historically been part of the educational benefit of library and information resources. There is a danger of professional self-importance here, combined with a confusion about the value of the difficulty inherent in an information activity.

In fact, just as easy-to-use Library portals may reproduce some of the poor types of information use encouraged by internet search engines, so can 'difficult' mechanical information skills teaching encourage inappropriate information use. We know that bad internet searching often leads to a 'more is better' approach, marked by indiscriminately citing too much poorly digested, poorly evaluated data. But in the example from practice cited above, once students had mastered the significant mechanical difficulties of a range of recommended search tools, this mechanistic approach to information skills teaching also led to a 'more is better' approach, marked by citing too much poorly digested, poorly evaluated data.

No matter the type of information tool, or the type of support required for the user of the tool, it is always possible to miss the educational point of both tools and teaching. It is even arguable that, because the tradition of 'bibliographic instruction' has been marked by too much focus on the mechanisms of information use, not the educational or intellectual benefits of using information and library resources, this tradition may have predisposed today's internet search engines users to see these new tools as the answer to all of their information problems.

Arguably therefore, the biggest advance in the last fifty years of the information revolution has not been the advance in the tools at hand (the

This is a peer-reviewed author accepted manuscript of the following research article: Joint, N. (2005), "Traditional bibliographic instruction and today's information users", Library Review, Vol. 54 No. 7, pp. 397-402. https://doi.org/10.1108/00242530510611884 
change from paper to electronic), phenomenal though these have been. After all, there have always been tools and these have always tended to improve, albeit at varying rates. The real advance has been in our improved ability to stand back and think about how we use information. This advance is to be identified with the birth of the information literacy movement in the 1970s, rather than the advent of mainframe computers in online retrieval in the late 1960s or the advent of widely available commercial web browsers in the 1990s.

Librarians themselves have not always applied the benefits of this great step forward in thinking about information use to their professional work. The example from practice cited above is a 'mea culpa' in proof of this. This discrepancy undermines the impact of librarians' criticism of new, non-library tools as 'information illiterate'. For librarians to be custodians of the highest standards of intelligent information use, they must develop and demonstrate a tradition of meaningful understanding and application of information literacy in their everyday practice. Without this, information users will rightly turn to new, non-mediated forms of information use and both they and the profession itself will be the poorer as a result.

Nicholas Joint,

Editor,

'Library Review'.

\section{References}

American Library Association Presidential Committee on Information Literacy (1989), Final report, American Library Association, Chicago.

Duff, A.S. (2003) "Four "e"pochs: the story of informatization." Library Review, 52(2): pp. 58-64

Eisenberg, M.B. and Berkowitz, R.E. (1990), Information problem-solving: the Big Six skills approach to library and information skills instruction. Ablex Publishing Corporation, Norwood, NJ.

Joint, N. (2005) "Editorial: Evaluating the quality of library portals." Library Review, 54(6): in press.

This is a peer-reviewed author accepted manuscript of the following research article: Joint, N. (2005), "Traditional bibliographic instruction and today's information users", Library Review, Vol. 54 No. 7, pp. 397-402. https://doi.org/10.1108/00242530510611884 
Owusu-Ansah, E. (2005) "Debating definitions of information literacy: enough is enough!" Library Review, 54(6): in press.

Plutchak, T.S. (1989) "On the satisfied and inept end user." Medical Reference Services Quarterly 8(1): pp 45-8.

The TLTSN initiative: The Teaching and Learning Technology Support Network < http://www.gla.ac.uk/rcc/projects/tltsn/ > (Accessed 9th May 2005).

Zurkowski, P.G. (1974), The information environment: relationships and priorities, National Commission on Libraries and Information Science, Washington D.C. 